\title{
STUDENTS' ATTITUDES IN LEARNING ENGLISH FOR TOURISM USING GOOGLE CLASSROOM IN MATARAM TOURISM COLLEGE
}

Ida Nyoman Tri Darma Putra

\author{
English Lecturer, Sekolah Tinggi Pariwisata Mataram, Indonesia
}

Corresponding Author Email: Ida.nyoman.putra@gmail.com

\begin{tabular}{l}
\hline A R T I C L E I N F O \\
\hline Article History: \\
Received: May, 2020
\end{tabular}

Revised: June, 2020

Published: June, 2020

Keywords:
Attitudes,
English,
Google Classroom,
\begin{abstract}
Mataram College of Tourism. The variables examined in this study include aspects of ease in accessing, usefulness, communication and interaction, and students' satisfaction in learning using google classroom. The result of this research shows that students in Mataram Tourism College feel accessing Google Classroom is easy to access, useful, easy for communication and interaction and feel satisfying with Google Classroom. From the interview, the respondents agree that Google Classroom offers helpful features that support the lecturers to manage the course efficiently and effectively. However, from the interview, it was found that the respondents felt that the quality of the learning processing was not better than conventional methods and they were uncomfortable during the learning processing in the google classroom.

The development of information and technology continues to grow in this the internet. It influences the world of education, especially in learning methods. One of the developments in education and learning methods to identify how students' responses towards learning English Profession using Google Classroom which is applied to the teaching and learning process at the Mataram College of Tourism. This research is survey research. The number of samples of this study was 135 students from
\end{abstract}

How to cite: Putra, I. (2020). Students' Attitudes in Learning English for Tourism Using Google Classroom in Mataram Tourism College. Jo-ELT (Journal of English Language Teaching) Fakultas Pendidikan Bahasa \& Seni Prodi Pendidikan Bahasa Inggris IKIP, 7(1), 9-17. doi:https://doi.org/10.33394/jo-elt.v7i1.2735

\section{INTRODUCTION}

Education as part of the life system in society, it always develops and changes. Changes in the development of science and technology will require educational institutions to produce qualified and competitive graduates. Moreover, in order to develop human resources for tourism quality standards. The Mastery of English is one of the basic requirements to be able to compete in the globalization and revolution industry 4.0 era, (Putra, 2018).

The development of information and technology continues to develop, especially in the development of technology with the internet very rapidly affecting the world of education, especially in learning methods. One of the online learning methods that are currently being developed and put into use is google classroom. it is an application that is devoted to online learning media so that it can facilitate teachers and lecturers in making, sharing each assignment online. The use of Google Classroom will make learning more effective because it can be accessed at any time through the Google classroom. 
Nowadays, the millennial generation always uses gadgets every day and always connects to the internet. Students can use their smartphones to take classes or study online without leaving home. In addition, in 2020 people is very familiar with the internet and using the internet in learning. One of the well-known and easy-to-use learning media for online learning is to use Google Classroom. The utilization of Google Classroom can be through a computer or smartphone. Google classroom is an application created by Google that aims to help lecturers and students to organize classes and communicate with students without having to be bound by class schedules in class. Besides that, lecturers can give assignments and directly give grades to the students. Learning material can be conveyed with Google classroom by utilizing the internet. Google Classroom is the use of learning media which uses the internet and improves students' knowledge and skills.

Google Classroom helps in realizing learning objectives and makes it easier for both lecturers and teachers to manage to learn and convey information accurately and precisely to students (Hakim, 2016). Through learning with blended learning, students feel comfortable and active in constructing their knowledge. Some features provided by Google Classrooms such as assignments, grading, communication, time-cost, archive courses, mobile applications, and quizzes. Therefore, the results of this study are expected to provide a further understanding of learning English with google classroom so that it can be used as an alternative learning. Many lecturers and teachers use conventional methods where lecturers dominate learning activities. Implementation of learning with Google Classroom is expected to help lecturers evaluate the implementation of teaching and learning for a better way and understanding in the future.

E-learning allows users to access learning course anywhere with the internet. According to Agarwal \& Pandey (2012), e-learning focuses on the use of technology in learning and education. E-learning refers to the use of information and communication technology in the learning process that consists of electronic media. According to Guri-Rosenblit (2005), Elearning is the use of electronic media for various learning purposes which range from conventional function in the classrooms to face-to-face meetings with online conferences". Stockley (1996-2017) states, e-learning involves the use of electronic devices in several ways to provide educational training or learning objectives. Sangra et.al (2012) said e-learning can be defined as the natural evolution of distance learning that uses the latest tools in the context of technology for regulation in education.

From this definition, we can conclude that e-learning utilizes electronic devices to provide educational online learning. E-learning simplifies the teaching and learning process because it excels in several ways such as sharing material or files, submitting assignments, and quizzes. E-learning has also been applied in many educational institutions. Through elearning, both lecturers or teachers and students can easily communicate. Besides that, it is easier for lecturers or teachers to provide feedback on assignments.

Google Classroom is a tool that facilitates student and teacher collaboration; teachers can also create and distribute assignments for students in online classes for free (Beal, 2017). Google Classroom can be a tool that makes students actively participate in the course. Nagele (2017) stated that teachers can make active, student-centered, collaborative, and unforgettable lessons only through Google Classroom. Google Classroom is useful for all categories of students and includes adult learners. Learning with Google Classroom is very efficient because it does not use paper, can be accessed anywhere and anywhere as long as there is an internet connection and can be accessed from any device. It also provides communication and interaction between teachers and students, provides feedback, and customized course learning. It has adequate learning feature that makes the teacher actively create and deliver assignments and also provide feedback to students. Google Classroom makes it easy for educators to manage student work assignments. 
Utilizing Google Classroom is very easy, firstly, sign in using https://classroom.google.com/, and sign in using a Google account with an email address. To create a first class, click the "+" button next to the email address. "Create class" will appear. After that, add the class name. The teacher can add details about the class, such as descriptions and instructions for students on the "about" tab, and also the Google Drive folder for class material and can attach course outlines and lesson plans. Finally, the class is ready and students can freely join if they have an email account and they must find the class code in the "stream" tab. Many activities we can do with Google Classroom when class is conducted such as making announcements, giving announcements about class updates, attaching class files and materials, making and uploading assignments for students with the due date, downloading material that has been uploaded by the teacher, making questions for discussion, and reusing posts like, announcements, assignments, and questions in other classes.

Google Classroom provides helpful features for its users such as free of charge, mobilefriendly, and time-saving. Moreover, Google Classroom is also very easy to use. Based on Janzen (2014), "The design of Google Classroom deliberately simplifies the instructional interface and the options used to send and track assignments; communication with the course or individual is also simplified through announcements, emails, and notifications". Using Google Classroom costs nothing. It's free for anyone as long as they are connected to the internet and can be used on any mobile device as long as there is an internet connection. Janzen (2014) also states that access to learning material that is interesting and easy to interact is very important in a learning environment that is connected to the internet. By using Google Classroom, teachers and students can save their time. According to Iftakhar (2016), Google Classroom can be integrated with other Google applications, such as, google documents, google Slides, Google Drive, and Google Spreadsheets.

However, Google Classroom also has some limitations as mentioned by Pappas (2015) such as limited integration options, no automatic updates, difficulty in sharing, and editing problems. It also has a problem with managing instructional materials and setting deadlines for assignments because Google Classes are not synchronized with Google Calendar or other calendars. Some Google Classrooms buttons are only familiar to Google users. In addition, students cannot share their documents with others without permission from the teacher. Students can only edit assignments after they create and distribute them to Google Classroom. They can save and delete any part of the assignment.

Nevertheless, we can conclude that Google Classroom is a good thing for students and educators such as lecturer and teachers because it is easy to use, efficient, and effective. It also provides a better environment and allows collaboration between teachers and students to be easier. With Google Classroom, the learning process can be effective and efficient because students and teachers can access Google Classroom anytime and anywhere with electronic devices via an internet network.

Media has an important role in learning. The media can get students and teachers involved in the class. Media in the classroom creates new learning experiences and hones critical thinking skills. Meanwhile, Tileston (2003) states that media can have an effect on student modality, management of motivational behavior, achieve higher levels of thinking, and real-world applications. Thus, the media is important in the learning process. Media makes it easy to access information, makes the learning process interesting, and also makes students happy. The use of learning media can arouse desires, new interests, can motivate and stimulate learning activities and even affect the psychological of students (Sari, 2016).

The advantage of using media based on Pedagogy in Action (2018), such as; the media can attract students 'attention and retain students' interests, students can sharpen their analytical skills, enable students to see new concepts and examples, experience the world beyond their abilities. In addition to the many benefits, there are also a number of 
shortcomings that must be kept in mind when using media. The challenges of using media according to Perez (2015) are; how to apply media effectively, understand how it works, and how to integrate media in learning. Finally, using media in the classroom makes students aware of current changes in electronic communication. Through media, students not only learn to access material and information but also respect and are wise using the media. In addition, the use of smartphones and computers was also used for learning a language. From the results of previous studies in the use of computers as media showed students showed a positive attitude towards the use of computers in foreign language learning programs (Putra, 2019).

\section{RESEARCH METHOD \\ Research Design}

This study aims to identify how students' responses/attitudes towards learning English Profession using Google Classroom. Google classroom was applied for the teaching and learning media at the Mataram Tourism College. This research uses quantitative research methods based on the objectives and needs of the research. According to Creswell (2009), quantitative research is an approach to test the objective theory by examining the relationships between variables. These variables can be measured with instruments; thus, the amount of data can be analyzed using statistical procedures.

This research specifically can be classified as survey research. Survey research provides a quantitative or numerical description of trends, attitudes, or opinions of a population by studying the sample of the population (Creswell, 2009). The purpose of this survey is to explain the characteristics of a population. Basically, what researchers want to find is how members of the population are distributed themselves on variables or more (for example age, ethnicity, religion, attitudes towards school).

\section{Population and Sample}

This research was conducted at the Mataram College of Tourism. According to Arikunto (2006), the population is the whole subject of research. The population in this study consisted of 300 students based on the total active students at the Mataram Tourism College.

Samples are part of the population that has the same characteristics (Arikunto, 2006). The population of this study consisted of 300 students between 2018 and 2019. The sample selection technique in this study used probability sampling. This is a sampling technique that provides equal opportunity for each element (member) of the population to be chosen as a sample member. According to Creswell (2009), in probability sampling, a representative sample of a population provides the ability to generalize a population. The number of samples of this study was 135 students of Mataram Tourism College.

\section{Instruments}

Research instruments are tools that are selected and used by researchers in carrying out their activities to collect data, in order to make it systematic and easy (Arikunto, 2006). In this study, researchers used a questionnaire as an instrument. Student responses will be measured by a questionnaire as a research instrument adopted from Shaharanee et.al (2016), with an internet self-efficacy scale developed by Eastin \& LaRose as a reference.

The aspects of the questionnaire were ease of access (6 questions), Perceived use ( 7 questions), communication and interaction (6 questions), and student satisfaction (4 questions). They were measured with a Likert scale that consists of 5 measure scale.

\section{Data Analysis}

The questionnaire used in this study was taken from Shaharanee et.al (2016). The first part is designed to collect respondent information, such as name, age, gender, and the number 
of students. It is only general personal information for respondents to fill out a questionnaire. This questionnaire is presented by circling numbers $(1,2,3,4$, or 5). Variables will be measured on a 5 measure with a Likert scale from 1 (strongly disagree) to 5 (strongly agree). In quantitative research, there are two methods for analyzing data (descriptive statistics and inferential statistics). Descriptive statistics are statistics used to analyze data by describing the data that has been collected, because without intending to make general conclusions or generalizations. Meanwhile, inferential statistics are statistical techniques used to analyze sample data and the results are applied to populations. In addition, these statistics are very suitable for use when samples are drawn from well-defined populations, and samples are randomly collected. Sugiyono (2012) stated that the sampling technique is conducted randomly. The data collection techniques use quantitative research methods. The quantitative or statistical data analysis was used to test the hypotheses that have been set. The research method in this research was quantitative method because the data in this research was in the form of numbers. The following steps were used to analyze the data in this study:

1. Reviewing online learning with Google Classroom with Shaharanee et.al (2016) questionnaire was chosen as an instrument.

2. Check item at a time in the questionnaire to make sure that the meaning is easy to understand.

3. Distributing 23 questionnaire items to the respondents.

4. The results were analyzed using SPSS to analyze data from the questionnaire into a statistical package.

5. The main findings can be analyzed by looking at all the average scores from highest to lowest. High scores indicate that respondents are satisfied with Google Classroom; therefore, this shows that it is useful and efficient as an active learning media. Low scores indicate that respondents are not satisfied.

\section{RESEARCH FINDINGS AND DISCUSSION}

\section{Research Findings}

Based on the results of the questionnaire answered by the respondents, the average of Ease of Access is shown in the table below.

Table 1

Mean score of Google Classroom Ease of Access Aspect

\begin{tabular}{|l|c|}
\hline \multicolumn{1}{|c|}{ Statement } & MEAN \\
\hline Signing on to the Google Classroom & $\mathbf{3 . 7 2}$ \\
\hline Accessing course materials & $\mathbf{3 . 3 3}$ \\
\hline Sending and receiving assignments & $\mathbf{3 . 7 2}$ \\
\hline Submitting assignments & $\mathbf{3 . 6 1}$ \\
\hline Navigating the system & $\mathbf{3 . 3 3}$ \\
\hline Easy to understand the system & $\mathbf{3 . 4 3}$ \\
\hline
\end{tabular}

Table 1 describes the ease of access of Google Classroom. The highest average is from question number 1 (signing on the google classroom) with a score of 3.72. Thus, it can be 
concluded that respondents feel signed on to the Google classroom is easy in Google Classroom. From the questionnaire and interview, the majority of the respondents agree that it is easy to access the classroom. This result is similar to Iftakhar (2016), that among students' participants of his research, agreed that Google Classroom was effective and easy to use.

Table 2

Mean Score for Perceived Usefulness

\begin{tabular}{|c|c|}
\hline Statement & MEAN \\
\hline $\begin{array}{l}\text { The quality of learning activity was } \\
\text { excellent }\end{array}$ & 2.96 \\
\hline $\begin{array}{l}\text { Google classroom is an excellent medium } \\
\text { for social interaction (lecturer vs students } \\
\text { and students vs students) as demonstrated } \\
\text { by this activity }\end{array}$ & 3.03 \\
\hline $\begin{array}{l}\text { Google Classroom helps me to submit } \\
\text { assignments on time }\end{array}$ & 3.48 \\
\hline $\begin{array}{l}\text { The course activities helped me to examine } \\
\text { issues, to evaluate new ideas, and to apply } \\
\text { what I have learned }\end{array}$ & 3.22 \\
\hline $\begin{array}{l}\text { The feedback provided by the lecturer is } \\
\text { useful }\end{array}$ & 3.40 \\
\hline $\begin{array}{l}\text { The grading system in Google classroom } \\
\text { help in monitoring my performance and } \\
\text { understanding the current topic discussed }\end{array}$ & 3.22 \\
\hline $\begin{array}{l}\text { The subject objectives, assessments and } \\
\text { content were consistent with the aid of } \\
\text { Google Classroom }\end{array}$ & 3.29 \\
\hline
\end{tabular}

Table 2 describes the perceived usefulness of Google Classroom. The highest average is from question number 3 (Google classroom helps me to submit assignments on time) with a score of 3.48. From the questionnaire and interview, the respondents feel that the use of the classroom class is useful and efficient in time. The respondents can upload files at a time and can join the class from anywhere and anytime. This result is similar to Wijaya (2016), that they are already feeling the benefits provided by the e-learning itself. It also means that students benefit when using Google Classroom. However, the quality of the learning processing showed that the respondent did not find it better than the conventional learning method. 
Table 3

Mean Score for Communication and Interaction

\begin{tabular}{|l|c|}
\hline \multicolumn{1}{|c|}{ Statement } & MEAN \\
\hline $\begin{array}{l}\text { I felt comfortable conversing } \\
\text { through this medium for this } \\
\text { activity. }\end{array}$ & $\mathbf{2 . 9 8}$ \\
\hline $\begin{array}{l}\text { The lecturer helped to keep the } \\
\text { course participants engaged and } \\
\text { participated in productive } \\
\text { discussions. }\end{array}$ & $\mathbf{3 . 3 3}$ \\
\hline $\begin{array}{l}\text { I feel comfortable interacting with } \\
\text { other participants in this activity. }\end{array}$ & $\mathbf{3 . 1 2}$ \\
\hline $\begin{array}{l}\text { My point of view was } \\
\text { acknowledged by other participants } \\
\text { during this activity. }\end{array}$ & $\mathbf{3 . 2 0}$ \\
\hline $\begin{array}{l}\text { Lecturers are enthusiastic in } \\
\text { teaching and explaining via the } \\
\text { Google Classroom }\end{array}$ & $\mathbf{3 . 1 1}$ \\
\hline $\begin{array}{l}\text { Lecturers are friendly, approachable } \\
\text { and could be easily contacted. }\end{array}$ & $\mathbf{3 . 1 6}$ \\
\hline
\end{tabular}

Table 3 describes the communication and interaction of Google Classroom. The highest average is from question number 2 (keep participants engaged and participating in productive discussions) with a score of 3.33 . More than $30 \%$ of the respondent from the questionnaire felt that the use of the classroom was engaging during the course, everyone had the chance to convey their thoughts on the topic being discussed. However, from the score, it showed that the respondent was feeling uncomfortable during the learning processing in the classroom.

Table 4

Mean Score for Learners 'Satisfaction

\begin{tabular}{|l|c|}
\hline \multicolumn{1}{|c|}{ Statement } & MEAN \\
\hline The subject met my personal goal through the medium introduced & $\mathbf{3 . 1 5}$ \\
\hline I would recommend this method of learning to be applied to another appropriate subject & $\mathbf{3 . 2 1}$ \\
\hline Google classroom is my first choice in active learning compared to other methods & $\mathbf{3 . 1 0}$ \\
\hline I like the Google Classroom as a learning initiative and motivation booster & $\mathbf{3 . 1 1}$ \\
\hline
\end{tabular}

Table 4 describes the aspect of learners' satisfaction using Google Classroom. The highest average is from question number 2 (I would recommend this method of learning to be applied to another appropriate subject) with a score of 3.21. From the review, more than $65 \%$ of the respondents were satisfied with the google classroom as media for learning. This result is similar to Shaharanee et.al (2016) that many students feel satisfied with Google Classroom because of its effectiveness and efficiency. 


\section{Discussion}

Overall result of this study as follows, for the ease of access of Google Classroom, the highest mean score is about signing on the google classroom with a score of 3.72. it was found from the questionnaire and interview; the majority of the respondents agree that it is easy to access the classroom. Meanwhile, in the aspect of perceived usefulness, the highest mean score is related with whether Google classroom helps learners to submit assignments on time with a score of 3.48. Unfortunately, the quality of the learning processing showed the lowest score. In the aspect of communication and interaction, the highest average is from item number 2 (keep participants engaged and participating in productive discussions) with a score of 3.33. However, from the score, it showed that the respondents were uncomfortable during the learning processing in the classroom. Finally, for the aspect of learners' satisfaction using Google Classroom. The highest average is about recommending Google Classroom to be applied to another subject) with a score of 3.21. In the interview, more than $65 \%$ of the respondents were satisfied with the google classroom as media for learning. Therefore, from result of this study and interview with the respondents, the researchers suggest the following advices and guidance for a better way teaching with Google Classroom. First, the instructions to complete the assignments should be stated clearly. Second, an example for the assignment should be provided. Third, the rubric and criteria for assessment such as quiz and other form of assessment should be used in order to motivate learners. Fourth, time duration for submitting the assignment should consider the difficulty of the assignments.

\section{CONCLUSION}

In conclusion, this research shows that in general, students in Mataram Tourism College feel accessing Google Classroom is easy to access, useful, easy for communication and interaction and feel satisfying with Google Classroom. Google Classroom offers helpful features that support the lecturers to manage the course efficiently and effectively. Google Classroom is easy to use, free, paperless, and flexible for teaching language. However, from the interview, it was found that the respondents felt that the quality of the learning processing was not better than conventional methods and they were uncomfortable during the learning processing with google classroom.

\section{REFERENCES}

Agarwal, H., \& Pandey, G. N. (2012). Impact of E-Learning in Education. International Journal of Science and Research (IJSR).

Arikunto, S. (2006). Prosedur Penelitian Suatu Pendekatan Praktik. Jakarta: Rineka Cipta.

Beal, V. (2017). Google Classroom. Retrieved Juni $2^{\text {nd }}$, 2020, from Webopedia: http://www.webopedia.com/TERM/G/google-classroom.html.

Creswell, J. W. (2009). Research Design: Qualitative, quantitative, and mixed methods approaches. Los Angeles: SAGE Publications. Inc.

Guri-Rosenblit, S. (2005). 'Distance education' and 'e-learning': Not the same thing. Springer.

Iftakhar, S. (2016). Google Classroom: What Works and How? Journal of Education and Social Sciences, Vol. 3, 7.

Janzen, M. (2014). Hot team: Google Classroom. Retrieved Juni $2^{\text {nd }}, 2020$ from http://tlt.psu.edu/2014/12/04/hot- team-google-classroom/.

Nagele, N. (2017). Udemy. Retrieved Juni $2^{\text {nd }}$, 2020, from Udemy.com: https://www.udemy.com/googleclassroom/.

Pappas, C. (2015, August 20). Google Classroom Review: Pros and Cons Of Using Google Classroom In eLearning. Retrieved Juni $2^{\text {nd }}, 2020$ from elearningindustry: https://elearningindustry.com/google-classroom-review-pros-and-cons-of-using-googleclassroom-in-elearning. 
Perez, P. (2015, 9 28). securedgenetworks. Retrieved Juni $2^{\text {nd }}, 2020$ from https://www.securedgenetworks.com/blog/how-google-classroom-is-Imakinginteractive-learning-more-productive.

Putra, I. N. T. D. (2018). The Readiness of English Communication Skills of Mataram Tourism Vocational College Students For Asean Economic Community. Retrieved April 25, 2020 from http://139.59.120.216/index.php/joelt/article/view/2308/1617.

Putra, I. N. T. D. (2019). Analisis Attitude Mahasiswa Hospitality Sekolah Tinggi Pariwisata Mataram Terhadap Implementasi Computer-Assisted Language Learning. Retrieved April 25, 2020 from http://ejurnal.binawakya.or.id/index.php/MBI.

Sangra, A., Vlachopoulos, D., \& Cabrera, N. (2012). Building an inclusive definition of elearning: An approach to the conceptual framework. Retrieved Mei $23^{\text {rd }}, 2020$ from http://www.irrodl.org/index.php/irrodl/article/view/1161.

Sari, S. D. P. (2016). Manfaat media pembelajaran berbasis ICT (information and communication technology) dalam pembelajaran bahasa Indonesia. In N. Suryani (Ed.), Pengembangan ICT dalam Pembelajaran. Seminar Nasional Teknologi Pendidikan, Pascasarjana Program Studi Teknologi Pendidikan Universitas Sebelas Maret, Surakarta, 28 November 2015 (pp. 115-123). Surakarta: UNS.

Shaharanee, I. N., Jamil , J. M., \& Rod, S. S. (2016). Google Classroom As a Tool For Active Learning. AIP Conference Proceedings.

Stockley, D. (1996-2017). E-learning Definition and Explanation (Elearning, Online Training, Online Learning). Retrieved Juni $2^{\text {nd }}, 2020$ from www.derekstockley.com.au: http://www.derekstockley.com.au/elearning- definition.html.

Sugiyono. (2012). Metode Penelitian Kuantitatif Kualitatif dan R\&D. Bandung: Alfabeta.

Tileston. (2003). The Importance of Media in the Classroom. SAGE Publishing.

Wijaya, A. (2016). Anlysis of Factors Affecting the Use of Google Classroom to Support Lecturers. The 5th ICIBA 2016, International Conference on Information Technology and Engineering Application, (61-68). Palembang-Indonesia. 